\title{
Influence of Dental Exposure to Oral Environment on Smear Layer Removal and Collagen Exhibition after Using Different Conditioning Agents
}

\author{
Lucas Amaral FONTANARI \\ Shelon Cristina Souza PINTO \\ Rodrigo CAVASSIM \\ Rubens SPIN-NETO \\ Eduardo de Paula ISHI \\ José Eduardo Cezar SAMPAIO
}

Department of Oral Diagnosis and Surgery, Araraquara Dental School, UNESP - Univ. Estadual Paulista, Araraquara, SP, Brazil

\begin{abstract}
Although in vitro studies have shown encouraging results for root surface conditioning with demineralizing agents, in vivo studies have failed to show its benefits in periodontal healing. This can be attributed to several factors, among which, the hypermineralization of dental surface. Therefore, this in vitro study compared, using scanning electron microscopy (SEM), the effect of root surface conditioning with different conditioners ( $1 \%$ and $25 \%$ citric acid, $24 \%$ EDTA and $50 \mathrm{mg} / \mathrm{mL}$ tetracycline hydrochloride) in impacted teeth and in teeth that had their roots exposed to the oral environment. One trained examiner assessed the SEM micrographs using a root surface modification index. There was a tendency of more root surface modification in the group of impacted teeth, suggesting that the degree of root mineralization influences its chemical demineralization.
\end{abstract}

Key Words: Smear layer, scanning electron microscopy, conditioning agents, hypermineralization.

\section{INTRODUCTION}

Root surfaces affected by periodontal disease become hypermineralized (1) and contaminated by bacteria (2) and their toxins (3). Scaling and root planning (SRP) is unable to completely decontaminate root surface and results in production of a smear layer (4), which is formed by remnants of calculus, plaque and contaminated dental hard tissues (cement and dentin) $(5,6)$. It might act as a barrier, preventing blood clot adhesion to the root surface (4) and periodontal regeneration (5). Root surface conditioning has been studied to overcome this problem. It is aimed at removing the smear layer and exposing the organic dental matrix rendering root surface more biocompatible, which may increase success in regenerative procedures (7).

Citric acid $(8,9)$, ethylenediaminetetraacetic acid (EDTA) (10-12) and tetracycline hydrochloride
(13) presented good results on root conditioning in vitro. Nevertheless, this has not been observed in vivo $(14,15)$. This unexpected result may be explained by the fact that root conditioning is influenced by the type of conditioner, the method of SRP (manual or ultrasonic) (16), the duration of the conditioning procedure (17), the mode of application of the conditioner (18), the concentration and $\mathrm{pH}$ of the conditioner (11), and probably the degree of root surface mineralization. This last factor is influenced by the length of time that the root surface is exposed to the oral environment. The degree of dental mineralization influences the demineralization and decontamination produced by chemicals used for root surface modification.

The aim of the present study was to assess the capacity of 3 conditioners (24\% EDTA, 1\% citric acid, $25 \%$ citric acid and $25 \mathrm{mg} / \mathrm{mL}$ tetracycline hydrochloride) to remove smear layer and expose organic dental matrix 
in radicular surfaces exposed or not to oral environment.

\section{MATERIAL AND METHODS}

This study was approved by the Research Ethics Committee of the Araraquara Dental School, UNESP Univ. Estadual Paulista (CEP-FOAr \#39/07). Seventy teeth were obtained from the undergraduate oral surgery clinic after patients signed an informed consent to use their extracted teeth. Thirty-five teeth had their root surface exposed to the oral environment. Inclusion criteria were used in order to standardize the conditions of these teeth as follows: 1 . age of the patients from 35 to 45 years old; 2 . root surface exposed due to periodontal breakdown and presenting calculus; 3 . probing depth to the selected tooth $\geq 4 \mathrm{~mm}$, with probing bleeding. The other 35 teeth were impacted teeth. The integrity of the cementoenamel junction (CEJ) was an inclusion factor for those teeth. After extraction, teeth were kept in saline (Merck, Darmstadt, Germany) to prevent dehydration and exposed and non-exposed teeth were maintained apart in different receptacles.

\section{Specimen Preparation}

Tooth segments were obtained from the mesial/ distal or buccal/lingual sides of the cervical third of the roots by making two parallel grooves with a \#2135 cylindrical bur (KG Sorensen, Barueri, SP, Brazil) under copious irrigation. The first groove was positioned horizontally at the CEJ and the second groove was made parallel and $4 \mathrm{~mm}$ apical in relation to the first. Only tooth segments that were able to provide the flattest specimens were selected. The area between the two grooves was then scaled with 50 apico-cervical strokes using a sharp \#5-6 Gracey curette (Hu-Friedy, Chicago, IL, USA).

Specimens were retrieved using a diamond disc (KG Sorensen), cutting off the crown at the first groove. Then a vertical section was performed to the second groove, producing two specimens of approximately $3 \times 4$ $\mathrm{mm}$ for each tooth segment. Specimens were stored in saline to prevent dehydration and those obtained from exposed and non-exposed teeth were maintained apart in different receptacles.

\section{Treatment Groups}

One hundred and forty specimens were obtained, being 70 specimens from teeth with radicular surfaces exposed to the oral cavity and 70 specimens from roots of impacted teeth. Specimens were subjected to different chemical treatments and each chemical treatment had its control group (treated with saline). Parameters used for each chemical treatment (concentration, duration and mode of application) were obtained from previous studies $(10,13)$. Each group was formed by 10 specimens $(n=10)$. Table 1 summarizes conditioning procedures in the experimental groups.

\section{Specimen Preparation for SEM Analysis}

After conditioning, specimens were subjected to a method that allows visualization of the collagen matrix in SEM micrographs (19): the 10 specimens of each group were allocated in codified cassettes. Then specimens were dehydrated by immersion in ethanol concentrations of $30,50,70,80,95$ or $100 \%$ ( $1 \mathrm{~h}$ in each solution), followed by immersion in a solution of $0.75 \mathrm{~mL}$ of $100 \%$ ethanol and $0.75 \mathrm{~mL}$ of hexamethyldisilazane (HMDS; Sigma-Aldrich Inc., St. Louis, MO, USA) for $30 \mathrm{~min}$ and a final immersion in $1 \mathrm{~mL}$ of pure HMDS for $10 \mathrm{~min}$. HMDS allows visualization of the collagen matrix in SEM micrographs. Finally, specimens were dried for $48 \mathrm{~h}$ in a dehydration jar (Corning, São Paulo, SP, Brazil), mounted on metallic stubs (Senai, São Paulo, SP, Brazil) for sputter coating with $99.99 \%$ pure gold.

\section{SEM Analysis}

Two SEM micrographs $(\times 1500$ and $\times 3500)$ from the center of each specimen were obtained with a scanning electron microscope (JEOL JSM-T330A; Jeol Ltd., Peabody, MA, USA). A previously trained blind examiner $(12,13)$ analyzed the micrographs at three moments according to a root surface modification scoring system, as follows: Score 1: absence of smear layer, showing denuded cement, and/or dentin and/or collagen fibers from dental matrix - "clean" specimens (Fig. 1A); Score 2: partially open dentin tubules and no collagen fibers exposure (Fig. 1B); Score 3: presence of smear layer (Fig. 1C); Score 4: smear layer formed by chemical dissolution of dentin surface (over demineralization) (Fig. 1D). The examiner was trained during 3 weeks before performing the analysis. For calibration purposes, SEM micrographs representative of the different scores were selected and 3 evaluations were performed per week with a 48 -h interval between each analysis. 

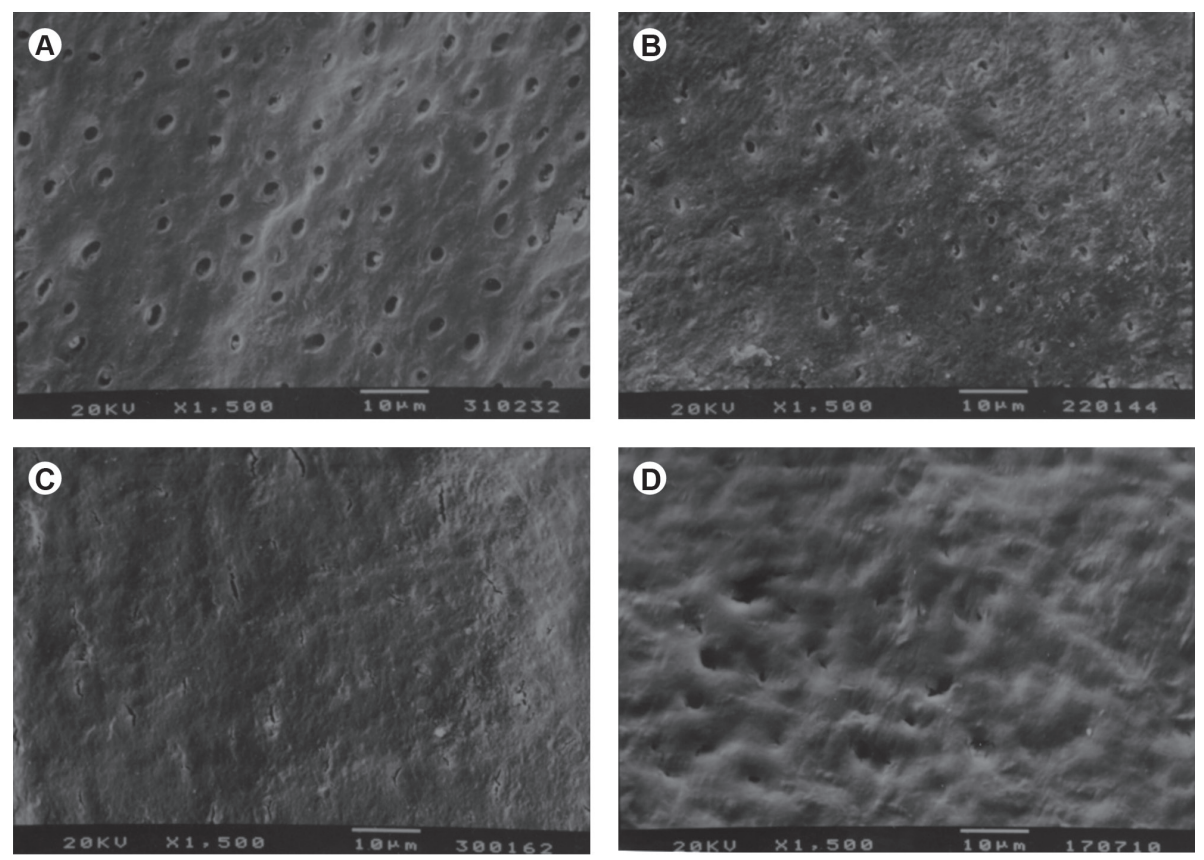

Figure 1. Root surface modification scores. A (Score 1) = no smear layer, denuded cement and/or dentin and/or collagen fibers from dental matrix - "clean" specimens; B (Score 2) = partially open dentin tubules and no exposed collagen fibers; C (Score 3)= presence of smear layer; D (Score 4) = smear layer formed by chemical dissolution of dentin surface (over demineralization).

Table 1. Conditioning procedures in the experimental groups.

\begin{tabular}{|c|c|c|c|c|}
\hline Group & Origin of root specimens & Type of conditioner & Mode of application & Duration of application \\
\hline IA & Impacted teeth (control group) & Saline & Cotton pellet (vigorous burnishing) & $3 \mathrm{~min}$ \\
\hline IB & Exposed roots (control group) & Saline & Cotton pellet (vigorous burnishing) & $3 \mathrm{~min}$ \\
\hline IC & Impacted teeth & $50 \mathrm{mg} / \mathrm{mL} \mathrm{TH}$ & Cotton pellet (vigorous burnishing) & $3 \mathrm{~min}$ \\
\hline ID & Exposed roots & $50 \mathrm{mg} / \mathrm{mL}$ TH & Cotton pellet (vigorous burnishing) & $3 \mathrm{~min}$ \\
\hline IIA & Impacted teeth (control group) & Saline & Soft brushing & $3 \min$ \\
\hline IIB & Exposed roots (control group) & Saline & Soft brushing & $3 \mathrm{~min}$ \\
\hline IIC & Impacted teeth & $25 \% \mathrm{CA}$ & Soft brushing & $3 \mathrm{~min}$ \\
\hline IID & Exposed roots & $25 \% \mathrm{CA}$ & Soft brushing & $3 \mathrm{~min}$ \\
\hline IIIA & Impacted teeth (control group) & Saline & Soft brushing & $1 \mathrm{~min}$ \\
\hline IIIB & Exposed roots (control group) & Saline & Soft brushing & $1 \mathrm{~min}$ \\
\hline IIIC & Impacted teeth & $1 \% \mathrm{CA}$ & Soft brushing & $1 \mathrm{~min}$ \\
\hline IIID & Exposed roots & $1 \% \mathrm{CA}$ & Soft brushing & $1 \mathrm{~min}$ \\
\hline IVA & Impacted teeth (control group) & Saline & Soft brushing & $3 \mathrm{~min}$ \\
\hline IVB & Exposed roots (control group) & Saline & Soft brushing & $3 \min$ \\
\hline IVC & Impacted teeth & $24 \%$ EDTA & Soft brushing & $3 \mathrm{~min}$ \\
\hline IVD & Exposed roots & $24 \%$ EDTA & Soft brushing & $3 \min$ \\
\hline
\end{tabular}

TH = tetracycline hydrochloride(Farmácia Santa Paula, São Paulo, SP, Brazil); CA = citric acid (Faculdade de Farmácia e Bioquímica, UNESP, Araraquara, SP, Brazil). The conditioning procedures assigned to groups IIA and IVA were the same, so there was an only experimental group $(n=10)$ to provide results for these two groups. The same is valid for groups IIB and IVB. 


\section{Statistical Analysis}

Statistical analyses were performed using GraphPad Prism software version 5.05 (Graph Pad Instat, San Diego, CA, USA). A non-parametric analysis of variance (Mann-Whitney test) was applied to compare groups using a $\mathrm{p} \leq 0.05$.

\section{RESULTS}

Results from specimens retrieved from teeth exposed to oral environment are presented in Figure 2. Control groups always received score 3. Score 1 was assigned only to $24 \%$ EDTA and $25 \%$ citric acid groups. Score 2 was the highest score attributed to the $50 \mathrm{mg} / \mathrm{mL}$ tetracycline hydrochloride and 1\% citric acid groups. Higher frequencies of score 4 were observed in the $24 \%$ EDTA and $25 \%$ citric acid groups.

Results from specimens retrieved from impacted teeth are presented in Figure 3. Control groups always received score 3 , except in the $25 \%$ citric acid control group. Score 2 was the highest score attributed to the $50 \mathrm{mg} / \mathrm{mL}$ tetracycline hydrochloride and $1 \%$ citric acid groups. Score 4 were assigned to $100 \%$ of the specimens belonging to the $24 \%$ EDTA and $25 \%$ citric acid groups.

Figure 4 shows frequency of scores of test groups in impacted teeth and in teeth exposed to oral environment. The highest frequency of score 2 in impacted teeth was observed in the $50 \mathrm{mg} / \mathrm{mL}$ tetracycline hydrochloride and $1 \%$ citric acid groups, while lower frequencies of this score was observed for the same conditioners when applied to teeth exposed to oral environment. The totality of specimens from impacted teeth treated with $24 \%$ EDTA and 25\% citric acid presented with score 4. Similarly, a high frequency of score 4 was observed when these 2 conditioners were applied to specimens from teeth exposed to oral environment.

\section{DISCUSSION}

Root surface conditioning studies present great variability in their results due to many factors, including the degree of root surface mineralization. The duration of root surface exposure to the oral environment (DES-RE process, dental plaque) implies the degree of mineralization (1), which might influence root surface modification. A hypermineralized root surface is harder to demineralize and decontaminate than a less mineralized one.

Figure 2, which presents results of specimens obtained from teeth exposed to oral environment, shows a poor capacity of $50 \mathrm{mg} / \mathrm{mL}$ tetracycline hydrochloride and $1 \%$ citric acid to remove smear layer (low frequency of score 2). This was expected since these agents present a lower demineralizing capacity $(6,9)$. This finding disagree with the results of a previous study (13), which

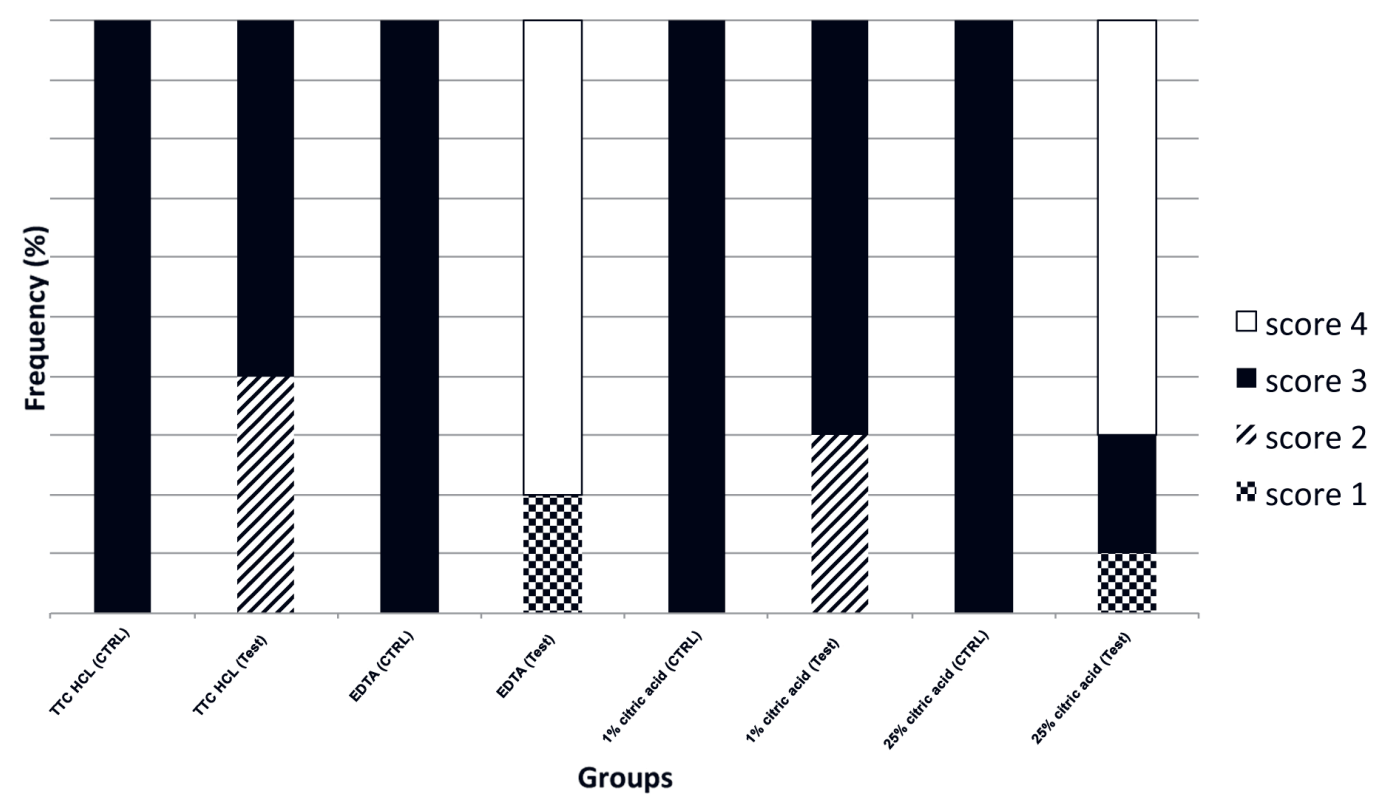

Figure 2. Frequency distribution of scores among specimens from teeth exposed to oral environment according to the treatment received. 
showed good demineralizing capacity to $50 \mathrm{mg} / \mathrm{mL}$ tetracycline hydrochloride, which could be attributed to the fact that this study did not control the root surface exposure to the oral environment factor.

The demineralizing action of citric acid has been shown to depend on its concentration (8) and high concentrations of citric acid (9) or EDTA (12) should be avoided since they produce smear layer as a result of over-demineralization, i.e., complete dissolution of the tooth surface.

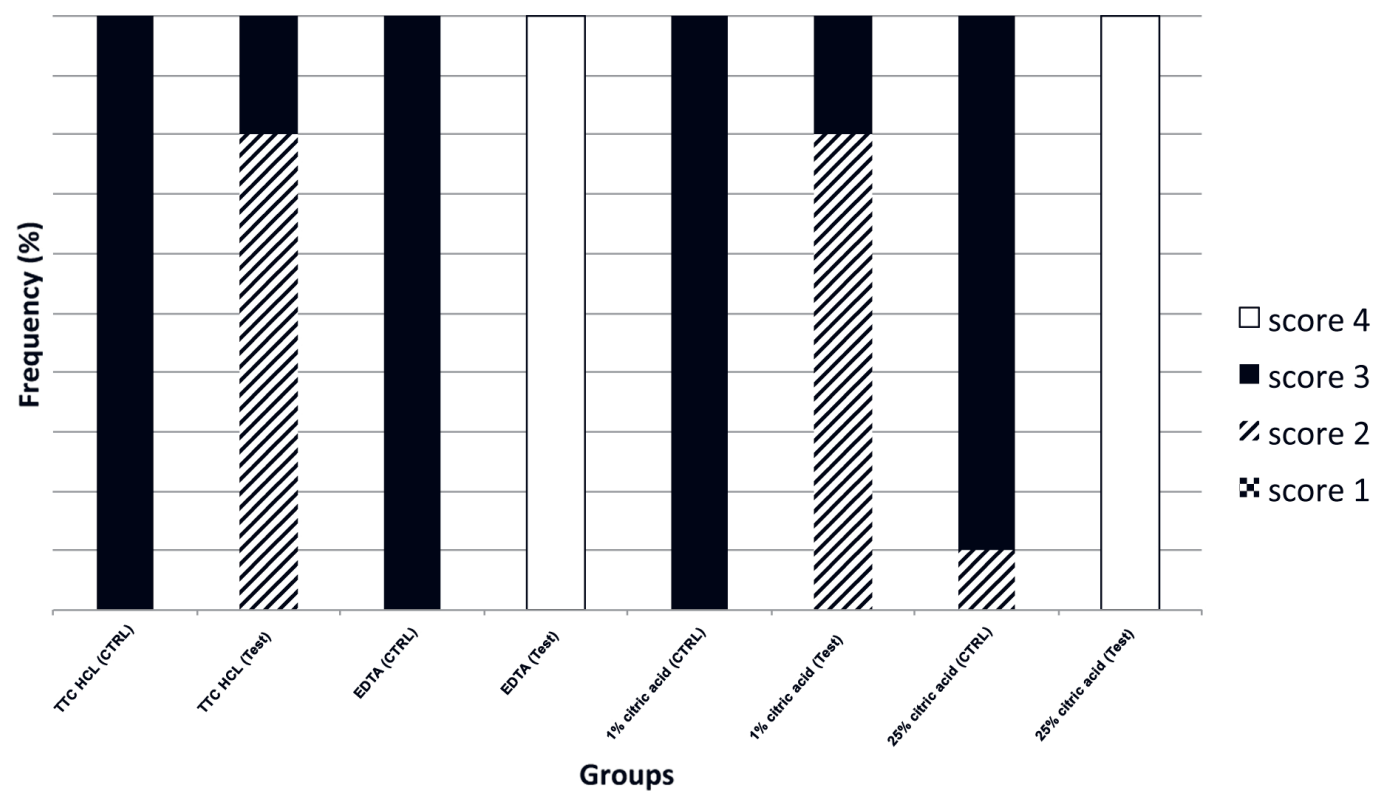

Figure 3. Frequency distribution of scores among specimens from impacted teeth according to the treatment received. * Statistically significant different results according to Wilcoxon test $(\mathrm{p}<0.05)$.

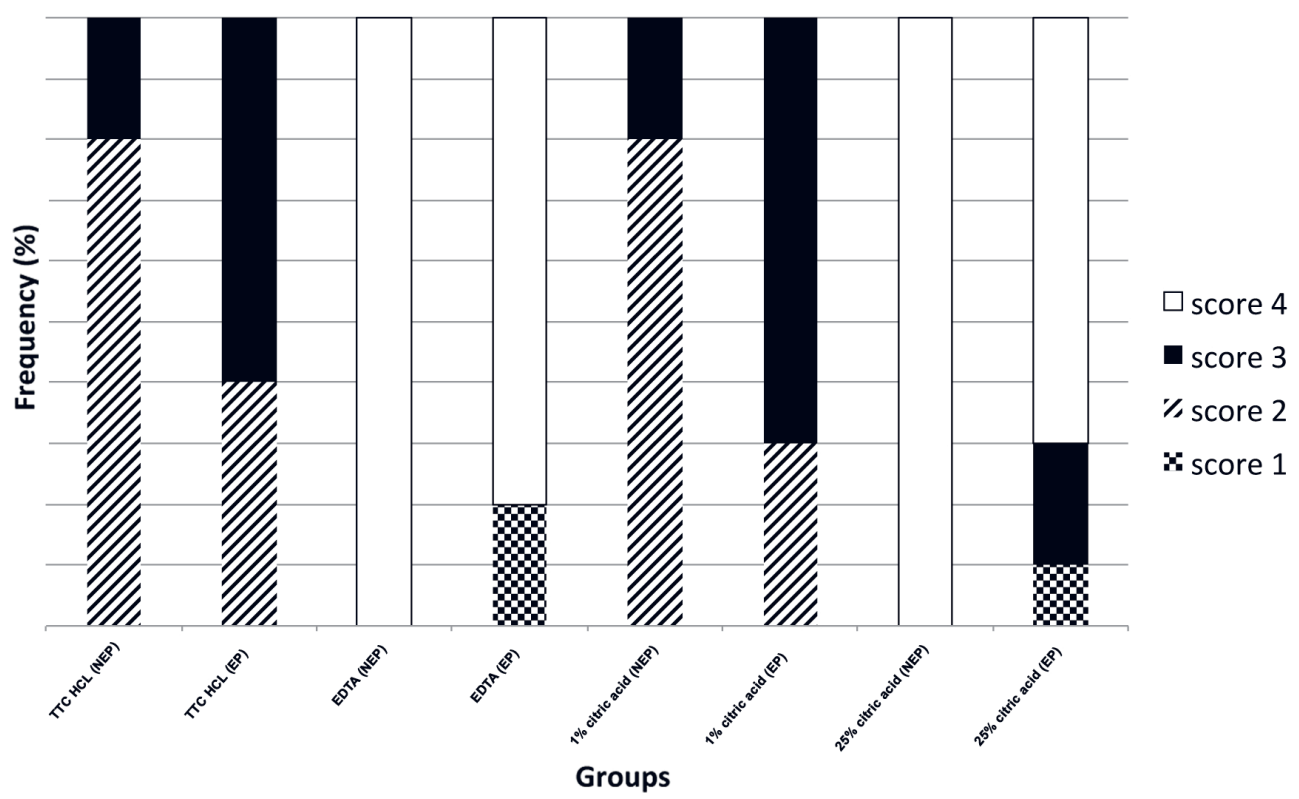

Figure 4. Frequency distribution of scores among specimens from impacted teeth and from teeth exposed to oral environment according to the treatment received. 
The high frequency of score 4 in the $24 \%$ EDTA gel group has not been shown before (12). This can be attributed to the fact that in the previous study (12) specimens were washed with $10 \mathrm{~mL}$ of saline between each 1-min gel application, which may wipe high surface tension gel (10) off the dental surface, reducing hypermineralization occurrence. The results of the present study suggest that while 24\% EDTA and $25 \%$ citric acid may hyperdemineralize dental surface (producing a "chemical dissolution" smear layer), $50 \mathrm{mg} /$ $\mathrm{mL}$ tetracycline hydrochloride and $1 \%$ citric acid have no efficacy in demineralizing supposedly hypermineralized dental surfaces.

Figure 3 shows results obtained in impacted teeth. As expected, 24\% EDTA and 25\% citric acid caused hyper-demineralization of dental surface. The $50 \mathrm{mg} / \mathrm{mL}$ tetracycline hydrochloride and $1 \%$ citric acid produced root demineralization and difference between these 2 groups and its controls was statically significant. The higher frequency of scores 1 and 2 in the $50 \mathrm{mg} / \mathrm{mL}$ tetracycline hydrochloride group corroborated previous results (13). The high frequency of score 2 in the 1\% citric acid group may be explained by the lower degree of dental surface mineralization found in impacted teeth. It can be inferred that less mineralized dental surfaces from impacted teeth are more easily demineralized than hypermineralized dental surfaces from oral environment exposed root surfaces.

Finally, Figure 4 compares the test specimens. It can be seen that the degree of root surface mineralization does not affect results obtained with 24\% EDTA and $25 \%$ citric acid, probably due to the high demineralizing potential of these agents which produced high frequency of specimens with hypermineralization. Comparing results obtained with $50 \mathrm{mg} / \mathrm{mL}$ tetracycline hydrochloride and $1 \%$ citric acid, it can be observed a tendency of specimens from impacted teeth to present higher degree of smear layer removal in relation to those from oral environment exposed root surfaces. The degree of mineralization may be responsible for this occurrence, suggesting that less mineralized dental surfaces from impacted teeth can be more easily demineralized than hypermineralized ones retrieved from root surfaces exposed to oral environment.

Under the tested conditions and considering the results obtained, it may be concluded that: $1.24 \%$ EDTA and $25 \%$ citric acid produced root surface hyper-demineralization; $2.50 \mathrm{mg} / \mathrm{mL}$ tetracycline hydrochloride and $1 \%$ citric acid showed greater smear layer removal capacity than the other two conditioners; 3. Although specimens from impacted teeth showed a tendency to have smear layer more easily removed, no significant difference was found in comparison with specimens obtained from teeth exposed to the oral environment.

\section{RESUMO}

Apesar de estudos in vitro terem demonstrado resultados favoráveis ao condicionamento da superfície radicular com agentes desmineralizantes, estudos in vivo não mostraram seus benefícios na cicatrização periodontal. Isto pode ser atribuído a vários fatores, entre os quais, a hipermineralização da superfície dental. Portanto, este estudo in vitro comparou, usando microscopia eletrônica de varredura, o efeito do condicionamento da superfície radicular com diferentes condicionadores $(1 \% \mathrm{e}$ $25 \%$ de ácido cítrico, EDTA $24 \%$ e $50 \mathrm{mg} / \mathrm{mL}$ de cloridrato de tetraciclina) em dentes impactados e dentes que tinham suas raízes expostas ao meio bucal. Um examinador treinado avaliou as microscopias eletrônicas de varredura utilizando um índice de modificação da superfície radicular. Houve uma tendência de maior modificação da superfície radicular no grupo de dentes impactados, sugerindo que o grau de mineralização da raiz influencia a sua desmineralização química.

\section{REFERENCES}

1. Wirthlin MR, Pederson ED, Hancock EB, Lamberts BL, Leonard EP. The hypermineralization of diseased root surfaces. J Periodontol 1979;50:125-127.

2. Kina JR, Kina J, Kina EF, Kina M, Soubhia AM. Presence of bacteria in dentinal tubules. J Appl Oral Sci 2008;16:205-208.

3. Carvalho Batista LH, Cezar Sampaio JE, Pilatti GL, Shibli JA. Efficacy of EDTA-T gel for smear layer removal at root surfaces. Quintessence Int 2005;36:551-558.

4. Baker DL, Stanley Pavlow SA, Wikesjo UM. Fibrin clot adhesion to dentin conditioned with protein constructs: an in vitro proof-ofprinciple study. J Clin Periodontol 2005;32:561-566.

5. Hanes PJ, Polson AM, Frederick GT. Initial wound healing attachments to demineralized dentin. J Periodontol 1988;59:176183.

6. Zaman KU, Sugaya T, Hongo O, Kato H. A study of attached and oriented human periodontal ligament cells to periodontally diseased cementum and dentin after demineralizing with neutral and low pH etching solution. J Periodontol 2000;71:1094-1099.

7. Larjava H, Salonen J, Hakkinen L, Narhi T. Effect of citric acid treatment on the migration of epithelium on root surfaces in vitro. J Periodontol 1988;59:95-99.

8. Sterrett JD, Bankey T, Murphy HJ. Dentin demineralization. The effects of citric acid concentration and application time. J Clin Periodontol 1993;20:366-370.

9. Cavassim R, Leite FR, Zandim DL, Dantas AA, Sampaio JE. Smear layer removal for collagen fiber exposure after citric acid conditionings. J Comtemp Dent Pract 2010;11:E001-E008.

10. Leite FR, Moreira CS, Theodoro LH, Sampaio JE. Blood cell attachment to root surfaces treated with EDTA gel. Braz Oral Res 2005;19:88-92.

11. Bergenholtz A, Babay N. Scanning electron microscopy of the root surface texture of extracted periodontally diseased teeth following 
various etching and chelating regimens. Int J Periodontics Restorative Dent 1998;18:171-179.

12. Sampaio JE, Theodoro LH, Correa MA, Mendes AJ. A comparative SEM study of smear layer removal by detergents and EDTA on the root surface. Int J Periodontics Restorative Dent 2005;25:157-163.

13. Ishi EP, Dantas AA, Batista LH, Onofre MA, Sampaio JE. Smear layer removal and collagen fiber exposure using tetracycline hydrochloride conditioning. J Contemp Dent Pract 2008;9:25-33.

14. Blomlof L, Jonsson B, Blomlof J, Lindskog S. A clinical study of root surface conditioning with an EDTA gel. II. Surgical periodontal treatment. Int $\mathrm{J}$ Periodontics Restorative Dent 2000;20:566-573.

15. Blomlof L, Bergman E, Forsgardh A, Foss L, Larsson A, Sjoberg B, et al.. A clinical study of root surface conditioning with an EDTA gel. I. Nonsurgical periodontal treatment. Int J Periodontics Restorative Dent 2000;20:560-565.

16. Martins Junior W, De Rossi A, Samih Georges Abi Rached R, Rossh MA. A scanning electron microscopy study of diseased root surfaces conditioned with EDTA gel plus Cetavlon after scaling and root planing. J Electron Microsc 2011;60:167-175.
17. Isik AG, Tarim B, Hafez AA, Yalçin FS, Onan U, Cox CF A comparative scanning electron microscopic study on the characteristics of demineralized dentin root surface using different tetracycline $\mathrm{HCl}$ concentrations and application times. J Periodontol 2000;71:219-225.

18. Codelli GR, Fry HR, Davis JW. Burnished versus nonburnished application of citric acid to human diseased root surfaces: the effect of time and method of application. Quintessence Int 1991;22:277-283.

19. Aoki K, Kitasako Y, Ichinose S, Burrow MF, Ariyoshi M, Nikaido et al.. Ten-year observation of dentin bonding durability of 4-META/MMA-TBB resin cement- a SEM and TEM study. Dent Mater J 2011;30:438-447.

Received October 7, 2010 Accepted September 8, 2011 